\title{
PENGARUH UMUR BIBIT DAN JUMLAH BIBIT TERHADAP PERTUMBUHAN DAN HASIL PANEN PADI SAWAH (Oryza sativa) VARIETAS CIHERANG
}

\section{EFFECT OF AGE OF SEEDS AND NUMBER OF SEEDS PER POINT OF PLANTING ON THE GROWTH AND PRODUCTION OF RICE (Oryza sativa) CIHERANG}

\author{
Marlina', Setyono'a, dan Y Mulyaningsih' ${ }^{1}$ \\ 1 Program Studi Agroteknologi, Fakultas Pertanian, Universitas Djuanda Bogor Jl. Tol Ciawi No. 1, \\ Kotak Pos 35 Ciawi, Bogor 16720. \\ a Korespondensi: Setyono, E-mail: setyono@unida.ac.id \\ (Diterima: 09-01-2017; Ditelaah: 10-01-2017; Disetujui: 25-02-2017)
}

\begin{abstract}
Rice is the staple food of Indonesia. Age of seeds and number of seeds per point of planting is one of the factors that need to be considered for rice cultivation efficiency. This study aims to determine the effect of age of seeds and the number of seeds per point of planting against Ciherang rice production. Experiments using a randomized block design with factorial treatment. The age of seedlings consists of two levels, namely the age of 15 days and 20 days after seedling, while the number of seeds per point of planting consists of 5 levels, namely 1, 2, 3,4 , and 5 seeds per point of planting. The results showed that the overall rice production was not affected by age of seeds and number of seeds per point of planting. Therefore, for the rice cultivation efficiency, it is suggested to use age of 15 days old seedlings with one seed per point of planting.
\end{abstract}

Keywords: age of seeds, rice, rice production, the number of seeds.

\section{ABSTRAK}

Padi adalah sumber makanan pokok bangsa Indonesia. Umur bibit dan jumlah bibit per titik tanam merupakan faktor yang perlu dipertimbangkan untuk efisiensi budidaya padi. Penelitian ini bertujuan mengetahui pengaruh umur bibit dan jumlah bibit per titik tanam terhadap produksi padi sawah varietas Ciherang. Percobaan menggunakan rancangan acak kelompok dengan perlakuan berpola faktorial. Faktor umur bibit terdiri atas 2 taraf, yaitu umur 15 hari dan 20 hari, sedangkan faktor jumlah bibit per titik tanam terdiri atas 5 taraf, yaitu 1, 2, 3, 4, dan 5 bibit per titik tanam. Hasil penelitian menunjukkan bahwa secara umum produksi padi tidak dipengaruhi oleh umur bibit dan banyaknya bibit per titik tanam. Oleh sebab itu untuk efisiensi disarankan menggunakan bibit berumur 15 hari dengan satu bibit per titik tanam.

Kata kunci: jumlah bibit, padi, produksi padi, umur bibit.

Marlina, Setyono, dan Y Mulyaningsih. 2017. Pengaruh umur bibit dan jumlah bibit terhadap pertumbuhan dan hasil panen padi sawah (Oryza sativa) varietas Ciherang. Jurnal Pertanian 8(1): 26-35.

\section{PENDAHULUAN}

Padi merupakan komoditas pangan sebagai bahan pokok karbohidrat yang strategis di Indonesia. Menurut BPS (2016) produksi padi tahun 2015 sebanyak 75,36 juta ton gabah kering giling (GKG) atau mengalami kenaikan sebanyak 4,51 juta ton $(6,37$ persen $)$ dibandingkan tahun 2014. Kenaikan produksi tersebut terjadi di Pulau Jawa sebanyak 2,31 juta ton dan di luar Pulau Jawa sebanyak 2,21 juta ton. Kenaikan produksi padi terjadi 
karena kenaikan luas panen seluas 0,32 juta hektar (2,31 persen) dan peningkatan produktivitas sebesar 2,04 kuintal/hektar (3,97 persen).

Beras adalah makanan pokok bangsa Indonesia, oleh sebab itu peningkatan kebutuhan beras sejalan dengan peningkatan jumlah penduduk. Namun, laju peningkatan produksi padi tidak sebanding dengan laju pertambahan penduduk, sehingga kadangkadang perlu mengimpor beras. Thomas Robert Malthus tahun 1789 menyatakan bahwa pertumbuhan populasi mempunyai kecenderungan meningkat melebihi dari ketersediaan pangan (Zaini 2008). Para ahli membuat terobosan-terobosan terhadap upaya peningkatan produksi padi untuk mengatasi ancaman kelangkaan pangan. Menurut Misran (2014) produksi padi ke depan harus terus ditingkatkan seiring dengan kenaikan jumlah penduduk. Untuk menjawab tantangan global, pemerintah telah menetapkan tujuan pembangunan tanaman pangan, yaitu: (1) meningkatkan produksi tanaman pangan dalam rangka mewujudkan ketahanan pangan nasional, (2) meningkatkan kesempatan kerja serta berusaha, dan (3) meningkatkan pendapatan serta kesejahteraan petani dan pelaku agribisnis lainnya, terutama di pedesaan.

Upaya peningkatan produksi padi telah berhasil secara nasional, namun dalam perkembangannya telah terjadi penurunan efektivitas dan efisiensi input (Departemen Pertanian 2008). Gejala tersebut ditandai dengan terjadinya penurunan efisiensi pemberian input, melandainya laju kenaikan hasil, menurunnya kesuburan lahan sawah, dan seringnya tanaman mendapat gangguan hama dan penyakit (Departemen Pertanian 2008). Penerapan inovasi pengelolaan tanaman terpadu (PTT) padi sawah spesifik lokasi dapat menjadi solusi permasalahan tersebut, karena PTT merupakan model inovasi dinamis dan kompatibel yang mengintegrasikan berbagai komponen teknologi (Departemen Pertanian 2008). Teknologi pemakaian umur bibit muda dan jumlah bibit yang relatif sedikit (1-3 batang per rumpun) merupakan salah satu komponen PTT.
Keberhasilan pengelolaan padi dipengaruhi oleh ketersediaan dan kemampuan tanaman dalam memanfaatkan sumber daya lingkungan, salah satunya dapat dicapai melalui penggunaan umur bibit yang tepat. Menurut Porong (2012) umur bibit 15 hari setelah semai (HSS) adalah yang tepat untuk pindah tanam, karena produksi lebih tinggi dan jumlah anakan lebih banyak dibandingkan umur 20 HSS, 25 HSS, 30 HSS, dan 35 HSS. Semakin cepat bibit pindah lapang akan semakin memadai untuk beradaptasi dengan lingkungan baru, sehingga semakin memadai dalam perkembangan anakan dan akar (Muyassir 2012). Kasim (2004) menyatakan bahwa umur bibit muda akan mempercepat pembentukan anakan, dan jumlah anakan dapat mencapai 40-80 batang per rumpun.

Pemakaian jumlah bibit padi per titik tanam dapat berpengaruh terhadap pertumbuhan. Pemakaian bibit dengan jumlah relatif banyak (5-10 batang per titik tanam), menyebabkan terjadinya persaingan sesama tanaman padi (kompetisi inter spesies) untuk mendapatkan air, unsur hara, C02, 02, cahaya, dan ruang untuk tumbuh, sehingga pertumbuhan menjadi tidak normal, mudah terserang hama penyakit, dan mengurangi hasil gabah (Abdullah 2004). Menurut Gandana (2011) rekomendasi yang umum untuk penggunaan jumlah bibit padi sawah adalah 1-3 batang per titik tanam. Pada teknologi SRI (The System of Rice Intensification) jumlah bibit yang diterapkan adalah 1 batang per titik tanam, karena dapat menghindari kompetisi inter spesies dan dapat mengurangi biaya produksi karena jumlah benih yang digunakan lebih sedikit (Kasim 2004).

Berdasarkan pernyataan para petani dan pengurus kelompok tani yang dihimpun selama bertugas menjadi penyuluh pertanian pada tahun 2012-2015 di Kabupaten Sukabumi, diperoleh informasi bahwa pada umumnya petani menanam padi varietas Ciherang. Varietas Ciherang merupakan varietas non lokal padi sawah yang dilepas tahun 2000 dengan nomor pedigri S3383-IdPn-41-3-1. Para petani berpendapat bahwa penggunaan varietas Ciherang didasari oleh 
bobot gabah lebih berat, nasi yang pulen, dan benih padinya lebih mudah didapatkan di pasaran pada saat musim tanam tiba, walaupun kurang tahan terhadap serangan hama dan penyakit.

Di daerah Pasekon Desa Cidahu Kecamatan Cibitung Kabupaten Sukabumi, pada umumnya para petani menggunakan bibit padi umur 20 hari setelah semai (HSS) dan jumlah bibit 4-6 batang per titik tanam. Petani beranggapan bahwa pada umur tersebut bibit akan lebih tahan terhadap serangan hama keong dan belalang. Jumlah bibit yang digunakan sekitar 4-6 batang per titik tanam karena petani khawatir tanaman padinya akan habis terserang hama, khususnya hama keong. Kebiasaan petani tersebut berbeda dengan anjuran penyuluh pertanian. Oleh sebab itu perlu kajian ilmiah mengenai umur bibit dan jumlah bibit per titik tanam padi varietas Ciherang yang tepat untuk daerah tersebut.

Dengan demikian tujuan penelitian ini adalah:

1. mengetahui pengaruh umur bibit dan jumlah bibit per titik tanam terhadap pertumbuhan dan hasil panen padi varietas Ciherang;

2. mendapatkan umur bibit dan jumlah bibit per titik tanam yang paling ideal untuk hasil panen maksimal padi varietas Ciherang secara spesifik lokasi di blok pasekon Desa Cidahu Kecamatan Cibitung Kabupaten Sukabumi.

\section{MATERI DAN METODE}

\section{Materi}

\section{Waktu dan Tempat}

Penelitian ini berbentuk percobaan lapangan yang dilaksanakan selama empat bulan, dimulai pada bulan Desember 2015 sampai bulan Maret 2016. Penanaman padi dilakukan di sawah milik petani dengan alamat Kp. Pasekon RT 10/RW 02 Desa Cidahu Kecamatan Cibitung Kabupaten Sukabumi Provinsi Jawa Barat, sedangkan sebagian penimbangan bobot gabah dilakukan di Laboratorium Universitas Djuanda Bogor.

\section{Bahan dan Alat Penelitian}

Alat yang digunakan pada penelitian ini meliputi meteran, timbangan, timbangan elektrik, cangkul, hand sprayer, hand traktor, ajir, dan pengukur $\mathrm{pH}$. Bahan yang digunakan meliputi benih padi varitas Ciherang, pupuk Urea, NPK Phonska, pestisida (insektisida dan fungisida) sebagai pembasmi hama penyakit.

\section{Metode}

\section{Rancangan Percobaan}

Rancangan percobaan yang digunakan adalah Rancangan Acak Kelompok (RAK) dengan alasan di sisi kiri kelompok 1 dan sisi kanan kelompok 3 terdapat tanaman padi milik petani yang berumur 2 MST, sedangkan di kelompok 2 sisi kiri dan kanannya hanya terdapat tanaman padi percobaan itu sendiri. Setiap perlakuan yang diterapkan pada petak percobaan diacak, dikelompokkan berdasarkan ulangan, dan disusun secara faktorial yang terdiri atas dua faktor yaitu umur bibit (A) dan jumlah bibit (B). Faktor umur bibit terdiri atas 2 taraf yaitu $A 1=$ umur bibit 15 HSS dan A2 = umur bibit 20 HSS, sementara itu faktor jumlah bibit terdiri atas 5 taraf yaitu B1 = 1 batang per titik tanam, B2 $=2$ batang per titik tanam, B3 = 3 batang per titik tanam, B4 $=4$ batang per titik tanam, dan B5 $=5$ batang per titik tanam.

Model linier Rancangan Acak Kelompok (RAK) yaitu:

$$
y i j k=\mu+A i+B j+(A B) i j+C k+\varepsilon i j k
$$

Keterangan: $\mathrm{y}_{\mathrm{ijk}}=$ Nilai respon pada umur bibit ke-i jumlah bibit ke-j kelompok ke-k; $\mu=$ Nilai tengah umum; $\mathrm{A}=$ Pengaruh umur bibit ke-i; $\mathrm{Bj}=$ Pengaruh jumlah bibit ke-j; $(A B)$ ij = Pengaruh interaksi umur bibit ke-i dan jumlah bibit ke-j; $\mathrm{Ck}$ $=$ pengaruh kelompok ke-k; $\varepsilon \mathrm{ijk}$ = Galat percobaan pada umur bibit ke-i dan jumlah bibit ke-j kelompok ke-k.

Setiap perlakuan menggunakan 3 ulangan, sehingga dibutuhkan 30 satuan percobaan. Setiap satuan percobaan ditempatkan di atas petakan sawah berukuran $(2 \mathrm{~m} \times 4,5 \mathrm{~m})$, dengan jarak tanam $(40 \mathrm{~cm} \times 30 \mathrm{~cm} \times 20 \mathrm{~cm})$, 
sehingga didapat 132 rumpun untuk setiap petakan.

Pengaruh perlakuan diuji dengan uji $\mathrm{F}$ (analisis ragam). Apabila hasil sidik ragam menunjukkan bahwa perlakuan berpengaruh nyata maka dilanjutkan dengan uji beda nilai tengah respon antar taraf perlakuan menggunakan uji DMRT pada taraf nyata 0.05.

\section{Pelaksanaan Penelitian}

\section{Persemaian}

Tahapan-tahapan yang dilakukan pada kegiatan persemaian yaitu pembuatan petak persemaian, perendaman benih, dan penebaran benih pada petak persemaian. Setiap tahapan dilakukan dua kali dalam waktu yang berbeda, yaitu untuk persemaian umur 15 HSS dan 20 HSS. Petak persemaian dibuat berupa bedengan pada lahan sawah yang dilakukan 5 hari sebelum penebaran benih, perendaman benih dilakukan selama 24 jam kemudian diinkubasi selama 30 jam, dan kegiatan terakhir yaitu penebaran benih pada petak persemaian secara merata.

\section{Pengolahan Tanah}

Pengolahan tanah dilakukan dengan menggunakan tenaga manusia dan mesin pertanian (hand traktor). Pengolahan tanah berlangsung kurang lebih selama seminggu, tahapan kegiatan yang dilakukan adalah perendaman tanah sampai titik jenuh, pemecahan bongkahan tanah, menggaru sampai tanah berubah menjadi lumpur. Empat hari pasca pengolahan tanah, dilakukan pembuatan petak percobaan sebanyak 30 petak dengan ukuran $2 \mathrm{mx} 4.5 \mathrm{~m}$.

\section{Penanaman}

Penanaman dilakukan dengan sistem jajar legowo, dengan tujuan untuk mengurangi serangan hama tikus dan keong mas serta memudahkan pada proses pemeliharaan. Penanaman dilakukan secara manual, menggunakan tenaga manusia. Kegiatankegiatan yang dilakukan pada proses penanaman meliputi pengambilan bibit pada petak persemaian (babut), pembuatan garis tanam dengan caplak legowo, dan penanaman bibit berdasarkan perlakuan pada petak percobaan yang sudah diacak dan dikelompokkan.

\section{Pemeliharaan}

Kegiatan pemeliharaan padi meliputi pengairan, pemupukan, pengendalian gulma, dan pengendalian hama penyakit. Pada fase vegetatif awal tanam sampai anakan maksimal dilakukan pengairan berselang 1:3 artinya 1 hari diairi dan 3 hari dikeringkan (tergantung cuaca dan tekstur tanah). Pada fase generatif dilakukan pengairan secara digenangi agar keluar malainya serempak. Pada fase pemasakan, yang ditandai dengan menuanya daun dan sudah berisinya gabah, lahan dikeringkan agar perubahan warna gabah serempak dan memudahkan panen. Kegiatan pemupukan dilakukan secara dialur dan diaplikasikan sebanyak tiga kali, yaitu pada umur 8 hari setelah tanam (HST), 28 HST, dan 42 HST. Pengendalian gulma dilakukan sebanyak dua kali, yaitu 5 hari setelah pemupukan pertama dan 3 hari sebelum pemupukan kedua (disesuaikan dengan kondisi di lapangan).

\section{Panen}

Kegitan panen dilakukan dengan kriteria gabah 95\% menguning dan daun sudah berwarna kuning serta kering. Pemanenan dilakukan secara manual dengan tenaga manusia.

\section{Peubah Pengamatan}

Pengamatan dilakukan setiap minggu, yang dimulai dari 1 minggu setelah tnam (MST) sampai panen. Peubah yang diamati pada penelitian ini adalah sebagai berikut.

1. Pertumbuhan jumlah anakan; dihitung berdasarkan jumlah tunas yang tumbuh pada saat fase vegetatif.

2. Pertumbuhan tinggi tanaman; diukur tinggi tanaman pada fase vegetatif mulai permukaan tanah sampai ujung daun tertinggi.

3. Umur berbunga; dihitung waktu munculnya bunga dari awal tanam.

4. Umur panen; dihitung waktu panen setelah tanam dengan kriteria gabah 85\%$90 \%$ sudah menguning dan berisi. 
5. Jumlah malai; dihitung jumlah malai per rumpun.

6. Panjang malai; dihitung dari pangkal malai sampai ujung malai.

7. Jumlah gabah per malai; dihitung baik yang hampa dan yang isi.

8. Persentase gabah isi; dihitung hanya gabah yang benar-benar berisi.

9. Bobot 1000 bulir; ditimbang bobot gabah sebanyak 1000 bulir dengan menggunakan timbangan elektrik.

10. Bobot gabah per rumpun; dihitung berdasarkan rata-rata bobot gabah setiap rumpun contoh yang diamati dari setiap petak percobaan.

11. Bobot gabah per petak; dihitung seluruh bobot gabah setiap petak percobaan.

\section{HASIL DAN PEMBAHASAN}

Penelitian berlangsung pada bulan Desember 2015 - Maret 2016. Selama penelitian berlangsung curah hujan rata-rata berkisar 12,84 dan $\mathrm{pH}$ tanah rata-rata berkisar 6,5. Pada umur 91 HST $90 \%$ padi sudah menguning serta berisi dan pada umur 95 HST dilakukan pemanenan.

\section{Hasil}

\section{Pertumbuhan Jumlah Anakan}

Hasil sidik ragam menunjukkan bahwa pertumbuhan anakan padi dipengaruhi oleh umur bibit (pada umur 2 dan 4 MST), jumlah bibit (pada umur 3 dan 4 MST), tetapi tidak dipengaruhi oleh interaksi keduanya. Pada umur 2 MST pertumbuhan jumlah anakan padi dengan perlakuan umur bibit 15 hari (A1) nyata lebih sedikit dibanding dengan umur bibit 20 hari (A2), sedangkan pada umur 4 MST perlakuan umur bibit 15 hari (A1) nyata lebih banyak dibanding dengan umur bibit 20 hari (A2) dan jumlah anakannya semakin banyak sampai umur 7 MST. Pada umur 3-4 MST pertumbuhan jumlah anakan padi dengan perlakuan jumlah 1 bibit (B1) dan 2 bibit (B2) tidak berbeda nyata dengan jumlah anakan 3 bibit (B3) dan 5 bibit (B5), tetapi nyata lebih sedikit dari jumlah 4 bibit (B4) (Tabel 1).

Tabel 1 Pertumbuhan jumlah anakan padi pada umur 1-9 MST

\begin{tabular}{|c|c|c|c|c|c|c|c|c|c|}
\hline \multirow{2}{*}{ Perlakuan } & \multicolumn{9}{|c|}{ Minggu Setelah Tanam (MST) } \\
\hline & 1 & 2 & 3 & 4 & 5 & 6 & 7 & 8 & 9 \\
\hline \multicolumn{10}{|l|}{ Umur bibit } \\
\hline A1 & 0,00 & $0,69^{a}$ & 3,76 & $7,29 b$ & 8,73 & 11,31 & 14,16 & 14,16 & 14,16 \\
\hline $\mathrm{A} 2$ & 0,07 & $1,53^{b}$ & 4,16 & $5,07^{a}$ & 7,11 & 9,56 & 12,71 & 12,71 & 12,71 \\
\hline \multicolumn{10}{|l|}{$\begin{array}{l}\text { Jumlah } \\
\text { bibit }\end{array}$} \\
\hline B1 & 0,06 & 0,89 & $2,72^{\mathrm{a}}$ & $4,44^{\mathrm{a}}$ & 6,56 & 9,61 & 13,78 & 13,78 & 13,78 \\
\hline B2 & 0,11 & 0,89 & $3,28^{a}$ & $5,44^{\mathrm{a}}$ & 7,61 & 10,17 & 13,28 & 13,28 & 13,28 \\
\hline B3 & 0,00 & 1,50 & $4,28^{\mathrm{ab}}$ & $6,72^{\mathrm{ab}}$ & 8,72 & 11,44 & 13,94 & 13,94 & 13,94 \\
\hline B4 & 0,00 & 1,44 & $5,89^{b}$ & $8,39^{b}$ & 9,94 & 12,44 & 15,89 & 15,89 & 15,89 \\
\hline B5 & $0,-00$ & 0,83 & $3,60^{\mathrm{a}}$ & $5,89^{a b}$ & 6,78 & 8,50 & 10,28 & 10,28 & 10,28 \\
\hline
\end{tabular}

Keterangan: Nilai rata-rata pada kolom yang sama diikuti huruf yang sama tidak berbeda nyata menurut uji DMRT pada taraf 5\%.

\section{Tinggi Tanaman}

Hasil sidik ragam menunjukkan bahwa tinggi tanaman padi dipengaruhi oleh umur bibit (pada umur 1, 2, dan 4 MST), jumlah bibit (pada umur 3 MST), tetapi tidak dipengaruhi oleh interaksi keduanya. Pada umur 1, 2, dan
4 MST tinggi tanaman padi dengan perlakuan umur bibit 15 hari (A1) nyata lebih rendah dibanding dengan umur bibit 20 hari (A2), pada awal pertumbuhan (1-4 MST) umur bibit 15 hari memiliki tinggi tanaman lebih rendah dari pada umur bibit 20 hari. Namun, pada 
pertumbuhan selanjutnya (6-9 MST) tinggi tanaman dengan umur bibit 15 hari mulai menyamai tinggi tanaman dengan umur bibit 20 hari. Pada umur 3 MST tinggi tanaman padi

Tabel 2 Tinggi tanaman padi pada umur 1-9 MST dengan perlakuan jumlah 1 bibit (B1) - 4 bibit (B4) tidak berbeda nyata, tetapi nyata lebih rendah dibanding jumlah 5 bibit (B5) (Tabel 2).

\begin{tabular}{|c|c|c|c|c|c|c|c|c|c|}
\hline \multirow{2}{*}{ Perlakuan } & \multicolumn{9}{|c|}{ Minggu Setelah Tanam (MST) } \\
\hline & 1 & 2 & 3 & 4 & 5 & 6 & 7 & 8 & 9 \\
\hline & \multicolumn{9}{|c|}{----------(cm)--------- } \\
\hline \multicolumn{10}{|l|}{ Umur bibit } \\
\hline A1 & $19,79^{a}$ & $27,30^{\mathrm{a}}$ & 37,18 & $45,73^{\mathrm{a}}$ & 59,83 & 67,69 & 73,14 & 85,53 & 89,02 \\
\hline $\mathrm{A} 2$ & $26,71^{\mathrm{b}}$ & $34,37^{b}$ & 39,67 & $51,32^{\mathrm{b}}$ & 61,41 & 66,39 & 77,54 & 85,96 & 86,41 \\
\hline \multicolumn{10}{|l|}{ Jumlah bibit } \\
\hline B1 & 23,61 & 29,64 & $36,86^{\mathrm{a}}$ & 47,33 & 59,06 & 65,53 & 77,06 & 85,11 & 88,28 \\
\hline B2 & 22,39 & 29,75 & $36,92^{\mathrm{a}}$ & 46,03 & 58,19 & 64,28 & 71,97 & 84,53 & 87,58 \\
\hline B3 & 22,22 & 30,39 & $37,33^{\mathrm{a}}$ & 47,89 & 60,86 & 66,50 & 75,47 & 86,00 & 87,47 \\
\hline B4 & 23,06 & 30,47 & $38,03^{a}$ & 46,33 & 59,75 & 65,78 & 74,03 & 85,31 & 87,03 \\
\hline B5 & 24,97 & 33,92 & $42,97 b$ & 55,06 & 65,25 & 73,11 & 82,19 & 87,78 & 88,22 \\
\hline
\end{tabular}

Keterangan: Nilai rata-rata pada kolom yang sama diikuti huruf yang sama tidak berbeda nyata menurut uji DMRT pada taraf 5\%.

\section{Umur Berbunga}

Hasil sidik ragam menunjukkan bahwa umur berbunga padi dipengaruhi oleh umur bibit dan jumlah bibit, tetapi tidak dipengaruhi oleh interaksi keduanya. Umur berbunga padi yang ditanam menggunakan bibit berumur 15 hari (A1) nyata lebih cepat dibanding padi yang ditanam dengan bibit berumur 20 hari (A2). Sementara itu padi yang ditanam dengan perlakuan 1 bibit (B1) - 4 bibit (B4) per titik tanam tidak berbeda nyata, tetapi nyata lebih lambat berbunga dibanding padi yang ditanam dengan perlakuan 5 bibit (B5) per titik tanam (Tabel 3).

Tabel 3 Umur berbunga

\begin{tabular}{cr}
\hline Perlakuan & \multicolumn{2}{c}{ Umur Berbunga (MST) } \\
\hline Umur bibit & $9,67^{\mathrm{b}}$ \\
A1 & $8,96^{\mathrm{a}}$ \\
A2 & \\
Jumlah bibit & $9,67^{\mathrm{b}}$ \\
B1 & $9,61^{\mathrm{b}}$ \\
B2 & $9,28^{\mathrm{b}}$ \\
B3 & $9,28^{\mathrm{b}}$ \\
B4 & $8,72^{\mathrm{a}}$ \\
B5 &
\end{tabular}

Keterangan : Nilai rata-rata pada kolom yang sama diikuti huruf yang sama tidak berbeda nyata menurut uji DMRT pada taraf 5\%.

\section{Jumlah Malai dan Panjang Malai}

Hasil sidik ragam menunjukkan bahwa jumlah malai dan panjang malai tidak dipengaruhi oleh umur bibit, jumlah bibit, dan interaksi keduanya. Jumlah malai dan panjang malai padi tidak berbeda nyata antar perlakuan. Secara umum setiap rumpun menghasilkan padi sekitar 14 malai dengan panjang malai sekitar $22 \mathrm{~cm}$ (Tabel 4).

Tabel 4 Jumlah malai dan panjang malai

\begin{tabular}{lrr}
\hline Perlakuan & Jumlah Malai & $\begin{array}{c}\text { Panjang } \\
\text { Malai }\end{array}$ \\
\hline Umur bibit & -malai/rumpun- & \multicolumn{1}{c}{- -cm-- } \\
A1 & 14,60 & 22,17 \\
A2 & 14,13 & 22,29 \\
\hline Jumlah bibit & & \\
B1 & 13,50 & 22,83 \\
B2 & 13,67 & 22,67 \\
B3 & 14,00 & 22,02 \\
B4 & 17,33 & 22,03 \\
B5 & 13,33 & 21,62 \\
\hline
\end{tabular}

Keterangan : Nilai rata-rata pada kolom yang sama diikuti huruf yang sama tidak berbeda nyata menurut uji DMRT pada taraf 5\%. 


\section{Jumlah Gabah Per Malai dan Persentase} Gabah Isi

Hasil sidik ragam menunjukkan bahwa jumlah gabah per malai dan persentase gabah isi tidak dipengaruhi oleh umur bibit, jumlah bibit, dan interaksi keduanya. Jumlah gabah per malai dan persentase gabah isi tidak berbeda nyata antar perlakuan (Tabel 5). Secara umum setiap malai menghasilkan gabah sekitar 118 bilir dengan gabah isi sekitar 92\%.

Tabel 5 Jumlah gabah per malai dan persentase gabah isi

\begin{tabular}{lrr}
\hline \multicolumn{1}{c}{ Perlakuan } & Jumlah Gabah & Gabah Isi \\
\hline & --bulir/malai-- & $----\%$---- \\
Umur bibit & & \\
A1 & 118,33 & 93,10 \\
A2 & 118,47 & 90,37 \\
Jumlah bibit & & \\
B1 & 129,67 & 92,80 \\
B2 & 123,17 & 90,93 \\
B3 & 118,00 & 92,38 \\
B4 & 112,00 & 93,33 \\
B5 & 109,17 & 89,25 \\
\hline
\end{tabular}

Keterangan : Nilai rata-rata pada kolom yang sama diikuti huruf yang sama tidak berbeda nyata menurut uji DMRT pada taraf 5\%.

\section{Bobot Gabah Padi}

Hasil sidik ragam menunjukkan bahwa bobot gabah 1000 bulir dan bobot gabah per rumpun tidak dipengaruhi oleh umur bibit, jumlah bibit, dan interaksi keduanya. Bobot gabah 1000 bulir dan bobot gabah per rumpun tidak berbeda nyata antar perlakuan. Rata-rata bobot 1000 bulir gabah kering giling (GKG) tidak kurang dari 24 gram, sedangkan rata-rata bobot gabah kering giling per rumpun sekitar 38 gram. Sementara itu bobot gabah kering panen (GKP) per petak dipengaruhi oleh jumlah bibit, tetapi tidak dipengaruhi oleh umur bibit dan interaksi keduanya. Bobot gabah kering per petak dengan perlakuan 1 bibit (B1) - 4 bibit (B4) per titik tanam tidak berbeda nyata, tetapi nyata lebih besar dibanding dengan perlakuan 5 bibit per titik tanam (B5). Dengan demikian terlalu banyak bibit per titik tanam justru tidak baik (Tabel 6).
Tabel 6 Bobot gabah padi

\begin{tabular}{|c|c|c|c|}
\hline \multirow{3}{*}{ Perlakuan } & \multicolumn{3}{|c|}{ Bobot Gabah } \\
\hline & $\begin{array}{l}1000 \\
\text { Bulir } \\
\text { (gr) }\end{array}$ & $\begin{array}{c}\text { Per } \\
\text { Rumpun } \\
\text { (gr) }\end{array}$ & $\begin{array}{c}\text { Per } \\
\text { Petak } \\
(\mathrm{kg})\end{array}$ \\
\hline & \multicolumn{2}{|c|}{--------GKG------- } & --GKP-- \\
\hline \multicolumn{4}{|l|}{ Umur bibit } \\
\hline $\mathrm{A} 1$ & 24,37 & 38,68 & 5,84 \\
\hline $\mathrm{A} 2$ & 24,67 & 37,46 & 5,40 \\
\hline \multicolumn{4}{|l|}{ Jumlah bibit } \\
\hline B1 & 24,73 & 40,65 & $5,69 b$ \\
\hline B2 & 24,78 & 37,56 & $5,57 \mathrm{ab}$ \\
\hline B3 & 24,03 & 38,14 & $5,98^{b}$ \\
\hline B4 & 24,43 & 43,81 & $6,00^{b}$ \\
\hline B5 & 24,63 & 30,18 & $4,88^{\mathrm{a}}$ \\
\hline
\end{tabular}

\section{Pembahasan}

Berdasarkan analisis ragam, pada semua peubah respon tidak ada pengaruh interaksi antara umur bibit dengan jumlah bibit per titik tanam. Dengan demikian analisis dapat dilakukan terhadap pengaruh umur bibit dan pengaruh jumlah bibit secara mandiri.

\section{Pengaruh Umur Bibit}

Data hasil penelitian menunjukkan perlakuan umur bibit tanaman padi tidak berpengaruh nyata terhadap jumlah malai, panjang malai, jumlah gabah per malai, persentase gabah isi, bobot 1000 butir, bobot gabah per rumpun, dan bobot gabah per petak. Hal tersebut memperlihatkan bahwa, umur bibit 15 hari dan 20 hari setelah semai memberikan dampak yang sama terhadap tujuh peubah tersebut. Namun demikian umur bibit berpengaruh nyata terhadap pertumbuhan jumlah anakan, tinggi tanaman, dan umur berbunga.

Pada awal pertumbuhan, tanaman padi dengan umur bibit 15 hari setelah semai memiliki pertumbuhan jumlah anakan dan tinggi tanaman yang lebih sedikit/rendah dibandingkan dengan umur bibit 20 hari setelah semai. Namun pada perkembangan selanjutnya, tanaman padi dengan umur bibit 
15 hari setelah semai memiliki laju pertumbuhan yang lebih cepat. Oleh sebab itu mulai umur 4 minggu setelah tanam, jumlah anakan tanaman padi dengan umur bibit 15 hari setelah semai menyamai jumlah anakan padi dengan umur bibit 20 hari setelah semai, dan pada umur 6 minggu setelah tanam, tinggi tanaman padi dengan umur bibit 15 hari setelah semai menyamai tinggi tanaman padi dengan umur bibit 20 hari setelah semai.

Jumlah anakan tanaman padi yang dihasilkan oleh umur bibit 15 HSS sebanyak 14.16 anakan, sedangkan tanaman dengan perlakuan umur bibit 20 HSS menghasilkan jumlah anakan sebanyak 12.71 anakan. Fakta tersebut menunjukkan bahwa tidak perlu ragu menggunakan bibit berumur 15 hari setelah semai, karena jumlah anakannya tidak kalah banyak dibandingkan tanaman yang menggunakan bibit berumur 20 hari setelah semai. Menurut Napisah dan Ningsih (2014), umur bibit 15 hari setelah semai merupakan umur pindah tanam yang lebih dapat beradaptasi dengan lingkungan

Semakin lama bibit berada di persemaian, diperkirakan pertumbuhan akar akan tetap berlangsung dan semakin memanjang. Pada saat pindah tanam kondisi sistem perakaran bisa mengalami kerusakan dan berpeluang besar bibit mengalami pertumbuhan yang tidak maksimal, karena fungsi akar sebagai penyerapan air dan unsur hara terganggu. Menurut Muyassir (2012) perpanjangan waktu pemindahan bibit ke lapangan mengakibatkan bibit stres karena terganggunya sistem perakaran dan membutuhkan waktu untuk masa penyembuhannya, sehingga waktu perkembangan anakan semakin pendek dan anakan yang dihasilkan semakin sedikit.

Pada minggu-minggu awal pindah tanam, tinggi tanaman padi dengan umur bibit 15 hari setelah semai lebih pendek dibandingkan tinggi tanaman padi dengan umur bibit 20 hari setelah semai. Namun memasuki minggu kelima tinggi tanaman sudah tidak dipengaruhi umur bibit. Bahkan pada minggu ke-9 tinggi tanaman padi dengan umur bibit 15 hari setelah semai mencapai $89.02 \mathrm{~cm}$, sedangkan tinggi tanaman padi dengan dengan umur bibit 20 hari setelah semai sebesar $86.41 \mathrm{~cm}$. Pada umur menjelang panen tinggi tanaman tidak lagi dipengaruhi oleh umur bibit dan lebih tergantung pada faktor genetis sehingga tinggi tanaman antar perlakuan hampir sama (Hermawati 2009).

Fase generatif pada tanaman padi ditandai dengan munculnya bunga. Umur berbunga tanaman padi nyata dipengaruhi oleh umur bibit. Padi dengan umur bibit 15 hari setelah semai berbunga pada umur 9.67 minggu, sedangkan padi dengan umur bibit 20 hari setelah semai berbunga pada umur 8.96 minggu. Namun kalau umur bibit diperhitungkan maka perlakuan tersebut tidak berpengaruh nyata karena keduanya mulai berbunga pada umur 82 hari setelah semai.

Pertumbuhan tanaman padi yang optimal bisa ditandai dengan adanya jumlah anakan yang lebih banyak, tinggi tanaman yang lebih tinggi, dan umur berbunga yang lebih cepat. Organ-organ tanaman padi yaitu akar, batang, dan daun berfungsi untuk mendukung dan menyelenggarakan proses pertumbuhan (Firmanto 2011). Umur berbunga padi bisa dipengaruhi oleh kondisi organ-organ tersebut, salah satunya akar. Akar berfungsi untuk menopang batang, menyerap air dan unsur hara (Purwono dan Purnamawati 2007). Jika kondisi sistem perakaran tanaman padi terganggu akibat proses pindah tanam padi dari persemaian ke lahan tanam, maka akar tidak akan berfungsi sebagaimana mestinya.

Jumlah malai, panjang malai, jumlah gabah per malai, persentase gabah isi, bobot gabah per 1000 bulir, bobot gabah per rumpun, dan bobot gabah per petak tidak dipengaruhi oleh umur bibit ketika pindah tanam. Berdasarkan uraian di atas maka tidak cukup alasan untuk menunda pindah tanam hingga bibit beumur 20 hari setelah semai atau lebih. Terlalu tua bibit dipindah tanam justru berdampak terganggunya perakaran yang membuat tanaman stres (Muyassir 2012).

\section{Pengaruh Jumlah Bibit}

Hasil analisis ragam menunjukkan bahwa jumlah bibit berpengaruh nyata terhadap pertumbuhan jumlah anakan, tinggi tanaman, umur berbunga, dan bobot gabah per petak, 
akan tetapi tidak berpengaruh nyata terhadap jumlah malai, panjang malai, jumlah gabah per malai, persentase gabah isi, bobot gabah 1000 bulir, dan bobot gabah per rumpun.

Pada awal pertumbuhan tanaman padi yaitu umur 1 minggu setelah tanam, pertambahan jumlah anakan baru dijumpai pada perlakuan jumlah bibit 1 batang dan 2 batang per titik tanam. Pada perkembangan selanjutnya yaitu umur 3 sampai 7 minggu setelah tanam, pertumbuhan jumlah anakan tanaman padi dengan perlakuan jumlah bibit 1 batang dan 2 batang per titik tanam tidak berbeda nyata dengan jumlah anakan tanaman padi dengan perlakuan jumlah bibit 3 batang dan 5 batang per titik tanam, tetapi berbeda nyata dengan perlakuan jumlah bibit 4 batang per titik tanam. Pada minggu-minggu berikutnya jumlah anakan tidak lagi dipengaruhi oleh perlakuan jumlah bibit per titik tanam. Oleh sebab itu penggunaan 1 bibit per titik tanam menjadi pilihan karena menghemat biaya produksi. Menurut Aliksa Organik SRI Consultant (2009), menanam satu batang per titik tanam dapat memberikan kesempatan kepada benih untuk menumbuhkan tunas yang lebih banyak, memberikan keleluasaan bergerak, dan menghindari kompetitif.

Pada awal pertumbuhan tinggi tanaman padi nyata dipengaruhi oleh perlakuan jumlah bibit. Pada umur 3 minggu setelah tanam, padi dengan perlakuan jumlah bibit 5 batang per titik tanam nyata lebih tinggi dari pada padi dengan perlakuan jumlah bibit 1-4 batang per titik tanam. Hal ini terjadi karena pada awal pertumbuhan tanaman belum memiliki anakan sehingga tanaman dengan bibit 5 batang per titik tanam tingkat persaingan mendapatkan cahaya relatif lebih tinggi sehingga cenderung mendorong tanaman tumbuh lebih tinggi. Namun pada perkembangan selanjutnya hingga tanaman berumur 9 minggu setelah tanam, tinggi tanaman padi dengan perlakuan jumlah bibit 1 batang sampai 4 batang per titik tanam menyamai tinggi tanaman padi dengan perlakuan jumlah bibit 5 batang per titik tanam. Pada saat itu anakan padi dari berbagai perlakuan jumlah bibit sudah relatif sama (sekitar $88 \mathrm{~cm}$ ) sehingga tidak ada perbedaan persaingan mendapatkan cahaya.

Jumlah bibit yang sedikit menyebabkan tanaman lebih banyak menerima intensitas cahaya matahari sehingga aktifitas fotosintesis berlangsung lebih baik (Misran 2014). Dilihat dari reaksi fotosintesis, laju fotosintesis dibatasi oleh ketersediaan $\mathrm{CO}_{2} \mathrm{di}$ sekitar daun, jika dalam satu rumpun jumlah tanaman lebih banyak maka posisi daun akan berhimpitan dan mengakibatkan terjadinya persaingan penggunaan $\mathrm{CO}_{2}$ di daerah sekitar daun.

Jumlah bibit tanaman padi berpengaruh nyata terhadap umur berbunga. Umur berbunga tanaman padi dengan perlakuan jumlah bibit 1 batang sampai 4 batang per titik tanam tidak berbeda nyata, tetapi lebih lambat berbunga dibandingkan dengan jumlah bibit 5 batang per titik tanam. Umur berbunga tanaman padi pada perlakuan jumlah bibit 5 batang per titik tanam 8.72 minggu setelah tanam, sedangkan tanaman padi dengan jumlah bibit $1-4$ batang per titik tanam berbunga setelah berumur 9 minggu. Diduga semakin banyak jumlah bibit padi yang ditanam akan semakin cepat tanaman padi memasuki fase generatif, karena sudah tidak memiliki ruang untuk melakukan pertumbuhan.

Jumlah gabah per malai, persentase gabah isi, bobot gabah per 1000 bulir, dan bobot gabah per rumpun tidak dipengaruhi oleh jumlah bibit per titik tanam. Kenyataan ini mendukung pernyataan bahwa penanaman padi tidak perlu lebih dari satu batang per titik tanam. Apalagi menurut Muyassir (2012) semakin banyak jumlah bibit per titik tanam cenderung meningkatkan kompetitif antara tanaman dalam satu rumpun dan rumpun lainnya terhadap cahaya, ruang, dan unsur hara sehingga mempengaruhi pertumbuhan dan produksi.

Jumlah malai, panjang malai, jumlah gabah per malai, persentase gabah isi, bobot gabah 1000 butir, dan bobot gabah per rumpun merupakan peubah yang tidak berbeda nyata di antara taraf perlakuan. Dengan demikian nilai dari keenam peubah tersebut lebih didominasi faktor bawaan dari genetik varietas Ciherang sendiri dibandingkan 
perlakuan umur bibit dan jumlah bibit per titik tanam. Hasil ini juga menunjukkan bahwa varietas Ciherang memiliki bobot biji yang seragam, yang volume lemma dan palea dari gabah ditentukan oleh faktor genetik tanaman itu sendiri. Cita rasa nasi dari padi varietas Ciherang tidak tergantung pada umur bibit dan jumlah bibit per lubang tanam.

\section{KESIMPULAN DAN IMPLIKASI}

Pada penelitian ini tidak ada pengaruh interaksi antara umur bibit dengan jumlah bibit per titik tanamn terhadap semua peubah pertumbuhan dan produksi padi varietas Ciherang. Umur bibit padi berpengaruh nyata terhadap pertumbuhan jumlah anakan dan tinggi tanaman pada minggu-minggu awal, dan tidak berpengaruh nyata ketika memasuki minggu-minggu akhir menjelang panen. Umur berbunga sejak pindah tanam dipengaruhi oleh umur bibit yang digunakan, tetapi jika dihitung sejak benih disemai tidak ada perbedaan umur berbunga.

Jumlah bibit padi berpengaruh nyata terhadap pertumbuhan jumlah anakan dan tinggi tanaman pada pertengahan pertumbuhan, tetapi tidak berpengaruh nyata ketika memasuki minggu-minggu akhir menjelang panen. Jumlah bibit per titik tanam berpengaruh terhadap umur berbunga, semakin banyak jumlah bibit semakin cepat berbunga. Namun bobot gabah per petak terendah justru terjadi pada tanaman padi dengan jumlah bibit terbanyak.

Berhubung pertumbuhan jumlah anakan, tinggi tanaman, umur berbunga, dan hasil panen sama baiknya, penggunaan bibit 1 batang per titik tanam lebih disarankan karena dapat menghemat penggunaan benih sehingga dapat meminimumkan biaya produksi. Selain itu disarankan menggunakan bibit berumur 15 hari, karena pada umur bibit yang lebih tua berpeluang terganggunya perakaran saat pindah tanam.

\section{DAFTAR PUSTAKA}

Abdullah S. 2004. Pengaruh perbedaan jumlah dan umur bibit terhadap pertumbuhan dan hasil padi sawah. Prosiding Seminar Nasional Penerapan Agroinovasi Mendukung Ketahanan Pangan dan Agribisnis 8:154-161.

Aliksa Organik SRI Consultan. 2009. Pertanian ramah lingkungan melalui metoda system of rice intensificatioan. Modul Training of Trainer, Banda Aceh.

BPS. 2013. Produksi padi nasional. Badan Pusat Statistik, Jakarta.

BPS. 2016. Berita Resmi Statistik No. 26/03/ Th. XIX, 01 Maret 2016

Departemen Pertanian. 2008. Panduan Pelaksanaan Sekolah Lapang Pengelolaan Tanaman Terpadu (SL-PTT) Padi. Badan Penelitian dan Pengembangan Pertanian, Jakarta

Firmanto BH. 2011. Sukses bertani padi secara organik. Angkasa, Bandung.

Hermawati T. 2009. Keragaman padi varietas indragiri pada perbedaan umur bibit dengan metode SRI (system of rice intensification). Percikan 99:111-115

Kasim M. 2004. Manajemen penggunaan air, meminimalkan penggunaan air untuk meningkatkan produksi padi sawah melalui sistem intensifikasi padi SRI (The System of Rice Intensification). Unand, Padang.

Misran. 2014. Efisiensi penggunaan jumlah bibit terhadap pertumbuhan dan produksi padi sawah. Pertanian Terapan 14:3947

Muyassir 2012. Efek jarak tanam, umur, dan jumlah bibit terhadap hasil padi sawah (Oryza sativa L). Manajemen Sumberdaya Lahan 1:207-212.

Napisah K dan Ningsih RD. 2014. Pengaruh umur bibit terhadap produktivitas padi varietas Inpari 17. Prosiding Seminar Nasional "Inovasi Teknologi Pertanian Spesifik Lokasi”. Banjarbaru.

Purwono dan Purnamawati H. 2007. Budidaya 8 jenis tanaman pangan unggul. Penebar Swadaya, Jakarta.

Zaini Z. 2008. Memacu peningkatan produksi padi sawah melalui inovasi teknologi budidaya spesifik lokasi dalam era revolusi hijau lestari. Orasi Riset Budidaya Tanaman. Bogor. 
